(C) 2022, The Authors. Published by Elsevier Inc. and Fass Inc. on behalf of the American Dairy Science Association ${ }^{\circledR}$. This is an open access article under the CC BY license (http://creativecommons.org/licenses/by/4.0/).

\title{
Evaluation of allergenicity of cow milk treated with enzymatic hydrolysis through a mouse model of allergy
}

\author{
Xiaona Liang, $\odot$ Zongzhou Wang, Hui Yang, Xue Luo, Jing Sun, Mei Yang, Xinyang Shi, Xiqing Yue,* ${ }^{\star}$ \\ and Yan Zheng* \\ College of Food Science, Shenyang Agricultural University, Shenyang 100866, P. R. China
}

\begin{abstract}
Cow milk (CM) allergy is a worldwide concern. Currently, few studies have been performed on the immunoreactivity of $\mathrm{CM}$ and fewer still on the antigenicity of $\mathrm{CM}$ in vivo and in vitro. In this study, we assessed the potential allergenicity of enzymatically hydrolyzed CM using in vitro ELISA and oral sensitization and challenge of BALB/c mice. Alcalase-, Protamex-, and Flavourzyme-treated CM (all from Novozymes) diminished IgE binding capacity, with greatest reductions of $56.31 \%, 50.62 \%$, and $56.45 \%$, respectively. Allergic symptoms and levels of total $\operatorname{IgG}_{1}$ were reduced, and allergic inflammation of the lung, jejunum, and spleen was relieved. Moreover, the numbers of $\mathrm{CD} 8^{+} \mathrm{T}$ and $\mathrm{B}_{22} 0^{+}$cells decreased, and the balance of $\mathrm{CD} 4^{+} \mathrm{T} /$ $\mathrm{CD} 8^{+} \mathrm{T}$ cells was effectively regulated. These findings suggest that the potential allergenicity of CM was reduced by enzymatic hydrolysis, and our research will lay a solid foundation for developing high-quality hypoallergenic CM products.
\end{abstract}

Key words: cow milk allergy, BALB/c mouse model, immunoreactivity, safety

\section{INTRODUCTION}

Food allergy is a growing health concern worldwide, with an increasing prevalence attributed to food, genetic, and environmental factors. Food allergy affects approximately 1 to $3 \%$ of adult and 5 to $8 \%$ of children (Ballmer-Weber and Fernández-Rivas, 2008). Food allergy is an IgE-mediated or non-IgE-mediated immune reaction, caused by certain foods or food additives (Petruláková and Valík, 2015). IgE-mediated food allergy occurs in approximately $50 \%$ of the food-allergic population. Studies have shown that many food components are linked to the IgE-mediated immune response. Cow

\footnotetext{
Received April 30, 2021.

Accepted October 8, 2021.

*Corresponding authors: yxqsyau@126.com and zhengyan0403@163 .com
}

milk (CM) is one of the chief food allergens, especially for children, which induces severe allergic reactions, such as diarrhea, dysrhythmias, and hypotension (Burney et al., 2010). Schouten et al. (2009) demonstrated that approximately 2 to $6 \%$ of infants and children exhibit cow milk allergy (CMA) in the first year of their life (Schouten et al., 2009). The antigenicity of CM is closely related to allergic protein constituents that can induce immune responses. Previous studies have suggested that some proteins, even lower contents of BSA, lactoferrin, and immunoglobulins, could induce CMA, in addition to the most prominent caseins and whey protein ( $\beta$-LG and $\alpha$-LA; El-Hatmi et al., 2015).

In recent years, several studies have attempted to explore possible processing methods to reduce potential food allergenicity, including thermal and nonthermal treatments (Toheder et al., 2016). Thermal treatment can reduce the antigenicity of food to an extent. Elagamy (2000) found that the immunogenicity and $\operatorname{IgE}$ binding capability of cow, buffalo, and camel milk was significantly reduced after heat treatment at $65^{\circ} \mathrm{C}$ for $30 \mathrm{~min}$, and these activities were entirely lost in cow and buffalo milk. Thermal treatment might destroy the quality and nutritional properties of food. However, nonthermal treatments have received much attention because they can completely preserve their nutritional quality and sensory properties. The most popular nonthermal treatments include high-pressure treatment, $\gamma$-irradiation, and enzymatic hydrolysis. Yang et al. (2017) suggested that the $\operatorname{IgE}$ binding capacity of walnut allergens subjected to high hydrostatic pressure and thermal treatment (conditions: $650 \mathrm{MPa}, 100^{\circ} \mathrm{C}, 15$ min) was efficiently reduced, with the highest reduction up to $86.37 \%$ (Yang et al., 2017). The types of foods that can be used for high-pressure treatment are limited. Despite the fact that the flavor and inherent nutritional quality is retained, high-pressure treatment has not been widely applied in food industry production. Lee et al. (2001) demonstrated that the antigenicity and allergenicity of bovine $\mathrm{CN}$ and $\beta$-LG were significantly reduced under $\gamma$-irradiation treatment, detected with inhibition ELISA. Today, $\gamma$-irradiation as a processing 
method is applied in the field of food production, but is not well accepted by consumers who are unaware of the technology. Calvo and Gómez proved that enzymatic hydrolysis and heat treatment lowered the content of $\beta-\mathrm{LG}$ and others in whey, and reduced the potential antigenicity of whey proteins (Calvo and Gómez, 2002). Similarly, Wróblewska and Troszyñska (2005) showed that enzymatic hydrolysis treatment with Alcalase significantly reduced the allergenicity of whey protein concentrate, which was further applied to the production of hypoallergenic formulas. However, these results were based on $\operatorname{IgE}$ or IgG binding capability in vitro, and very limited information exists about changes in allergenicity following gastrointestinal digestion.

Animal models can act as a direct tool to predict possible allergy triggers, identify possible allergic mechanisms, reflect the relevant clinical parameters of allergic responses, and evaluate the allergenic potential of food. In particular, in the study of CMA, BALB/c mice are commonly used in the evaluation of potential antigenicity. The BALB/c mouse model is prioritized for assessing sensitization of CM because it can generate specific $\mathrm{CM}-\mathrm{IgE}$ antibodies, which are similar to those produced by humans (Hsieh et al., 2003). In addition, an IgE-mediated BALB/c mouse model for oral administration of certain CM allergens leading to CMA has been introduced, which has been widely used to evaluate the allergenicity of CM (Stojadinovic et al., 2014).

Previous research has focused only on the allergenicity of specific proteins in CM, and few studies have investigated the antigenicity of CM. Thus, our work aims to explore the effect of enzymatic hydrolysis treatment on the potential allergenicity of CM. The potential allergenicity of enzymatically hydrolyzed CM (HM) was assessed by conducting an in vitro ELISA. The BALB/c mice in our study underwent oral sensitization and challenge. Clinical signs of the mice were monitored, morphological changes of different organs were evaluated, serum CM-specific antibodies were detected, and plasma histamine and splenic cytokine levels were measured. The data might provide significant information regarding CMA, and these results may provide more comprehensive guidance for developing hypoallergenic CM products.

\section{MATERIALS AND METHODS}

\section{Material}

Fresh CM samples were obtained from 120 healthy Holstein cows from a farm near Shenyang (Liaoning, China). Fresh CM samples had fat removed by highspeed centrifugation at $15,000 \times g$ for $30 \mathrm{~min}$ at $4^{\circ} \mathrm{C}$ and were stored at $-80^{\circ} \mathrm{C}$. Alcalase, Protamex, Flavourzyme, and Neutrase were acquired from Novozymes. Papain and pepsin were acquired from Sigma-Aldrich. Cholera toxin (CT) was obtained from Sigma-Aldrich. We purchased ELISA kits (mouse $\operatorname{IgG}_{1}$ and $\operatorname{Ig}_{2 \mathrm{a}}$ ) from eBioscience.

\section{Preparation of Samples}

Samples were prepared as previously described (Liang et al., 2021). Briefly, enzyme solutions $(0.1 \mathrm{~g} / \mathrm{mL})$ were prepared with Alcalase, Protamex, Flavourzyme, Neutrase, papain, and pepsin, respectively. The amount of enzyme solutions added depended on the enzyme activity-to-substrate ratio (E/S, 2,000-10,000 U/g). Solutions were incubated for $2 \mathrm{~h}$, and the reaction stopped by heating at $90^{\circ} \mathrm{C}$ for $10 \mathrm{~min}$, followed by cooling in ice water immediately. The solutions were centrifuged $\left(5,000 \times g, 10 \mathrm{~min}\right.$ at $\left.4^{\circ} \mathrm{C}\right)$ and freeze-dried, and then stored at $-80^{\circ} \mathrm{C}$ until further analysis.

\section{Human Serum Collection}

Human serum samples were obtained from 10 CMA patients (China Medical University, Shenyang, China). All subjects consented to the study before participating as donors. The availability of human serum samples has been approved by the ethical committee of the hospital (China Medical University, Shenyang, China). This study was approved by the Shenyang Agricultural University Institutional Review Board (Shenyang, China) and by the Chinese Human Research Ethics Committee (Beijing, China), which followed the Declaration of Helsinki and the Nuremberg Code. All the experiments were carried out in accordance with relevant Chinese laws and institutional guidelines. These patients had a severe CMA history, the specific IgE level of allergic serum was above 0.35 kilo units per liter (where $1 \mathrm{U}=$ $2.4 \mathrm{ng}$ ), and the clinical manifestations also confirmed allergic response. In addition, preparation of the human serum pool referenced the method reported previously by Wu et al. (2016).

\section{Western Blotting}

The IgE binding capacity of CM and HM was further analyzed using western blotting, which referenced the method reported previously by Liang et al. (2021). Briefly, protein content of samples was detected and separated with SDS-PAGE. The proteins were transferred from the unstained SDS-PAGE gel to polyvinylidene fluoride membranes using an iBlot Transfer Device (ThermoFisher Scientific), and the membranes were blocked (3\% BSA Tween 20 in Tris-buffered saline 
for $1 \mathrm{~h})$. Then, the membranes were incubated with the primary antibody (human serum, 1:20 dilution) and secondary antibody (anti-human IgE, 1:2,000). Blots were visualized with an enhanced chemiluminescence kit (Beyotime) according to the manufacturer's instructions. The image was visualized using a ChemiDoc imager (ChemiDoc MP, Bio-Rad Laboratories).

\section{IgE Binding Capability}

The IgE binding capabilities of $\mathrm{CM}$ and $\mathrm{HM}$ were evaluated by ELISA as described by Liang et al. (2021). Briefly, CM or HM was added to the microtiter plates in PBS $(100 \mu \mathrm{L}$ per well, $5 \mu \mathrm{g} / \mathrm{mL})$. The plates were washed with PBS-Tween $(250 \mu \mathrm{L}$ per well), and pooled serum (100 $\mu \mathrm{L}$ per well, 1:20 dilution) was applied, followed by rabbit anti-human IgE-peroxidase $(100 \mu \mathrm{L}$ per well, 1:2,000 dilution). Absorbance was detected at $490 \mathrm{~nm}$ using a microplate reader. The IgE reactivity reduction (\%) was calculated based on the following:

$\operatorname{IgE}$ reactivity reduction $(\%)=\frac{\mathrm{OD} 490 \mathrm{~nm}(\mathrm{CM}-\mathrm{HM})}{\mathrm{OD} 490 \mathrm{~nm}(\mathrm{CM})}$.

\section{Mouse Model Sensitization}

Mouse model sensitization was performed as previously described (Bai et al., 2020). A total of $60 \mathrm{BALB} / \mathrm{c}$ mice (female, 6-8 wk old) were acquired from Vital River Laboratory Animal Technology (Beijing, China). All animal-use protocols were approved the Ethical Committee for the Experimental Use of Animals at Shenyang Agricultural University (Shenyang, China; license no. SYXK Liao 2011-0001). All methods were performed in compliance with the guidelines for the care and use of laboratory animals published by the US National Institutes of Health (National Research Council, Institute for Laboratory Animal Research, 1996). All the mice were maintained at the laboratory of Shenyang Agriculture University with standard animal housing conditions (room temperature: $25 \pm$ $1{ }^{\circ} \mathrm{C}$; relative humidity: $45 \pm 5 \%$; light and dark cycle: 12:12 h) and acclimated for $1 \mathrm{wk}$. The mice were kept in cages in 5 groups of 12: the negative control group (NC), positive control group (PC), Alcalase-treated milk group (AT), Protamex-treated milk group (PT), and Flavourzyme-treated milk group (FT). All mice were sensitized intragastrically on d $0,7,14,21$, and orally challenged on d 28. Briefly, the NC group was sensitized with CT $(10 \mu \mathrm{g})$ in PBS $(300 \mathrm{~mL})$ and challenged with PBS (300 mL) alone. The PC group was sensitized with $300 \mathrm{~mL}$ of solution (PBS $+5 \mathrm{mg}$ of $\mathrm{CM}$ ) with $10 \mu \mathrm{g}$ of $\mathrm{CT}$, and challenged with $300 \mathrm{~mL}$ of solution (PBS $+20 \mathrm{mg}$ of $\mathrm{CM}$ ) alone; the AT, PT, and FT groups were sensitized with $300 \mathrm{~mL}$ of solution (PBS + $5 \mathrm{mg}$ of $\mathrm{HM}$ ) containing $10 \mu \mathrm{g}$ of $\mathrm{CT}$, and challenged with $300 \mathrm{~mL}$ of solution (PBS $+20 \mathrm{mg}$ of $\mathrm{HM})$. In the experiment, the protein content of CM was $260 \mathrm{mg} / \mathrm{g}$, and the amount of protein used for oral challenge was based on the protein content of CM. Thirty minutes after the last oral challenge, blood, jejunum, spleen, and lungs were collected for further analysis.

\section{Evaluation of Allergic Reactions}

The mice were monitored for 30 min after the last oral challenge; allergic symptoms were monitored in a blinded fashion by 3 experienced independent observers, and clinical scores were assessed according to a method reported previously (Candreva et al., 2016), with some slight modifications, as follows: $0=$ no reaction; 1 = reduced activity, random scratching (e.g., nose, mouth, head); 2 = abnormal breathing, swelling around the eyes and mouth, pillar erection; $3=$ shortness of breath, blue rash around the mouth and tail, higher breathing rate; $4=$ no activity, shivering and muscle contractions; $5=$ death by shock.

\section{Cutaneous Tests}

Cutaneous tests were based on the method described by Candreva et al. (2016), with slight modifications. The mice in these groups received a tail vein injection of $0.5 \%$ Evan's blue dye $(100 \mu \mathrm{L})$. A few minutes later, blue color was observed in the tail of the mice, to evaluate anaphylaxis-induced vascular leakage.

\section{Histopathological Studies of Different Organs}

After the final oral challenge, lungs, jejunum, and spleen were collected for histopathological studies. These samples were embedded in paraffin $(10 \%)$ and stained with hematoxylin and eosin. Histopathological analysis of these samples was performed using a microscope (Olympus BX 41).

\section{Quantification of Total Antibodies in Serum}

Assessment of total $\operatorname{IgG}_{1}$ and $\operatorname{IgG}_{2 \mathrm{a}}$ levels in serum was performed according to the method reported by Yang et al. (2018). Briefly, the antigen solution was coated onto ELISA plates $\left(100 \mu \mathrm{L}, 4^{\circ} \mathrm{C}\right.$, overnight). The plates were washed thrice with PBS-Tween and blocked with PBS containing $0.5 \%$ gelatin at $37^{\circ} \mathrm{C}$ for $1 \mathrm{~h}$, followed by primary and secondary antibodies, and incubated for $1 \mathrm{~h}$ at $37^{\circ} \mathrm{C}$. Finally, all the samples were reacted with ortho-phenylenediamine $(100 \mu \mathrm{L})$, 
followed by $2 \mathrm{M} \mathrm{H}_{2} \mathrm{SO}_{4}$ to terminate the reaction. The absorbance value was determined using an ELISA plate reader (BioTek Instruments Inc.) at $490 \mathrm{~nm}$.

\section{Immunophenotyping Study}

Single-cell suspensions of splenocytes were mixed with PerCP anti-mouse CD3e, fluorescein isothiocyanate (FITC) anti-mouse CD4, allophycocyanin (APC)stained CD8 antibodies (BD Pharmingen), and phycoerythrin (PE)-stained CD45R/B220 antibodies. The mixtures were incubated at $4^{\circ} \mathrm{C}$ in the dark for $30 \mathrm{~min}$. Subsequently, wash buffer was added, and the supernatant was discarded. Single cells were resuspended (flow buffer, $500 \mu \mathrm{L}$ ). The population of cells was identified using a FACSCalibur flow cytometer (BD Biosciences), following previously described protocols (Yadav et al., 2013).

\section{Statistical Analysis}

All the tests of the experiment were carried out in triplicate, at least. Data are presented as mean values \pm standard deviations. Statistical evaluation was performed with Student's $t$-test and analyzed using GraphPad Prism 8.0.2. Statistical significances were detected by one-way ANOVA, followed by Tukey's test with $\alpha$-level of 0.05 .

\section{RESULTS}

\section{IgE Binding Capacity Analysis}

Immunoreactivity of $\mathrm{HM}$ treated with 6 different enzymes was investigated in this study. As shown in Figure 1, the immunoreactivity of CM treated with Alcalase, Protamex, Flavourzyme, Neutrase, and pepsin significantly decreased, ranging from $44.07 \%$ to $7.63 \%$. Notably, when E/S reached 6,000 U/g, the immunoreactivity reached a maximum reduction (Alcalase, Protamex, Flavourzyme, Neutrase, and pepsin: 38.36, $34.22,44.07,31.27$, and $38.95 \%$, respectively). For papain, the immunoreactivity of HM varied depending on the E/S (from 2,000 to $4,000 \mathrm{U} / \mathrm{g}$ ), and the immunoreactivity was significantly reduced (from 25.55 to $31.66 \%$ ). However, the immunoreactivity significantly increased as E/S increased from 6,000 to $10,000 \mathrm{U} / \mathrm{g}$ (6,000: $-11.82 \%$; 8,000: $-14.62 \%$; 10,000: $-71.54 \%)$. Furthermore, Figure 1B shows that the immunoreactivity of CM obtained with Protamex and Flavourzyme did not significantly change with the time of enzymatic hydrolysis, indicating that the immunoreactivity of Protamex- and Flavourzyme-treated CM were not affected by treatment time. In addition, as the enzymatic

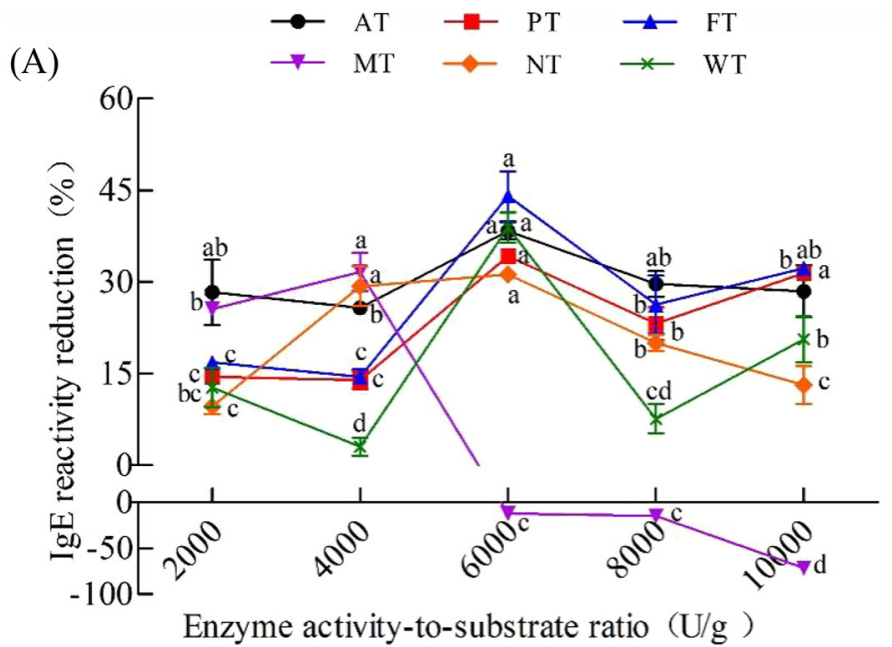

(B)

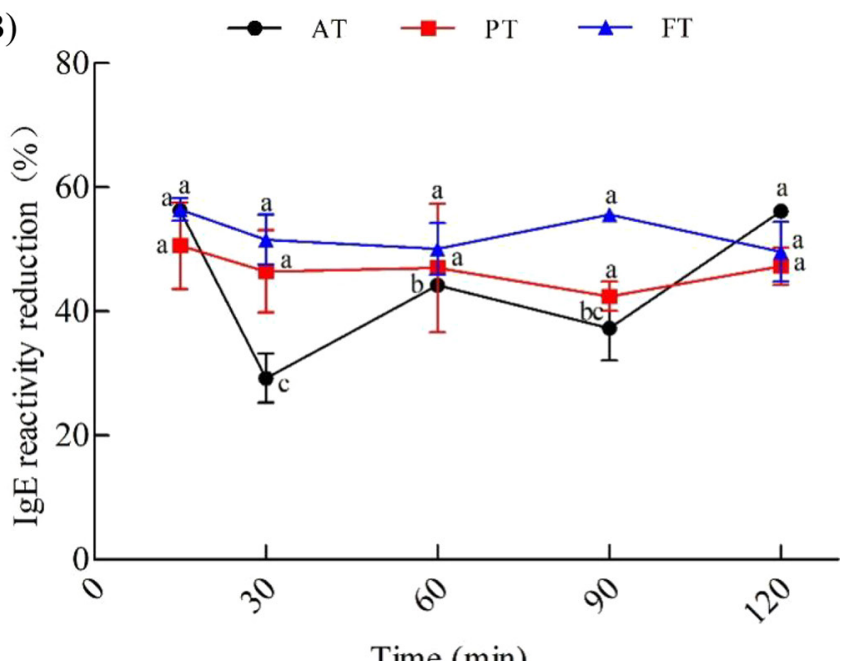

Figure 1. (A) Effects of enzymatic hydrolysis treatment on the inhibition of $\mathrm{IgE}$ binding with cow milk and hydrolyzed cow milk. Enzymatic hydrolysis treatment processed with different enzymes and different ratios of enzyme activity to substrate (from 2, 000 to 10,000 $\mathrm{U} / \mathrm{g}$ ). (B) Enzymatic hydrolysis treatment processed with different enzymes and enzymatic hydrolysis times (from 15 to $120 \mathrm{~min}$ ). $\mathrm{AT}=$ Alcalase-treated cow milk, PT $=$ Protamex-treated cow milk, FT = Flavourzyme-treated cow milk (all from Novozymes), MT = papaintreated cow milk, NT = Neutrase-treated cow milk (Novozymes), and $\mathrm{WT}=$ pepsin-treated cow milk. Different letters indicate significant differences among groups $(P<0.05)$. Error bars represent SD.

hydrolysis time reached $30 \mathrm{~min}$, the immunoreactivity of Alcalase-treated CM significantly increased (29.26\%; $P<0.05)$.

\section{Western Blotting Analysis}

To evaluate the immunoreactivity changes of $\mathrm{CM}$ and HM, western blotting analysis was performed. Figure 2 shows that the IgE binding capacity of $\alpha$-LA was stronger than that of the other proteins, and the $\operatorname{IgE}$ binding 

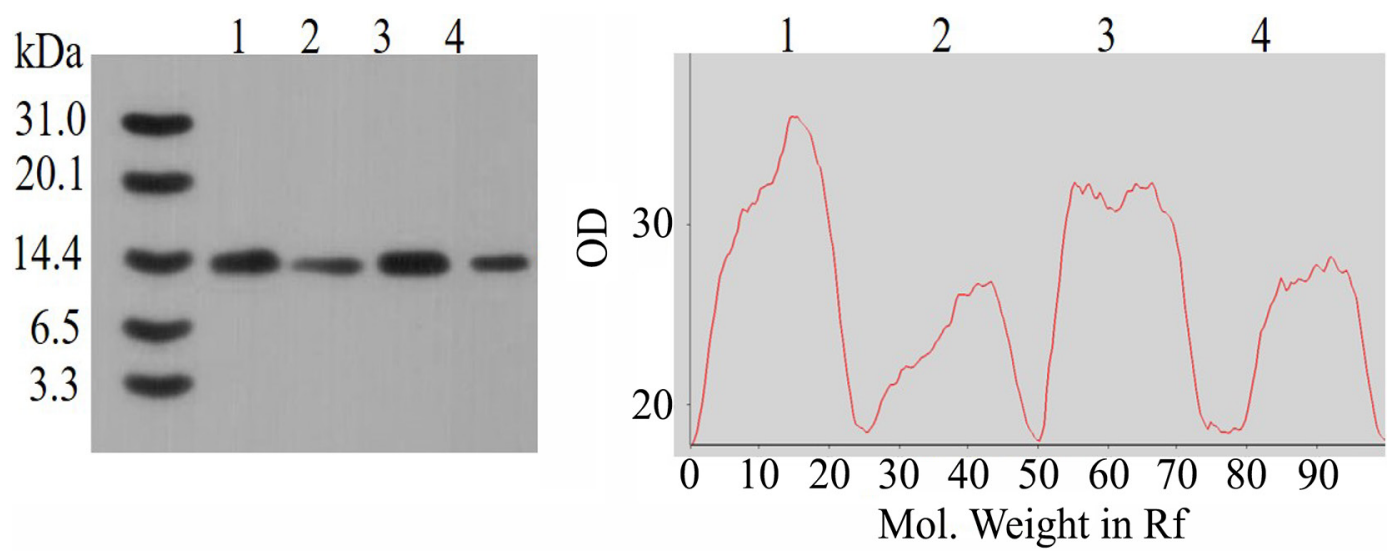

Figure 2. Immunoglobulin E binding capacity of cow milk $(\mathrm{CM})$ and hydrolyzed cow milk proteins in immunoblot analysis, using pooled sera ( $\mathrm{IgE}$ ) from patients allergic to milk. $\mathrm{M}=$ molecular weight marker; lane $1=\mathrm{CM}$; lane 2 = Alcalase-treated cow milk (AT); lane 3 = Protamextreated cow milk (PT); lane $4=$ Flavourzyme-treated cow milk (FT). The Rf value is calculated based on the position of the peak index in relation to the profile ( $\mathrm{Rf}=$ peak index/profile length). All enzymes were purchased from Novozymes. Different letters indicate significant differences among groups $(P<0.05)$. OD = optical density.

capacity of $\alpha$-LA in AT, PT, and FT was weaker than in CM. In addition, the IgE binding capacities of AT and FT were weaker than that of PT.

\section{Allergy Symptoms and Body Weight}

The allergenicity of $\mathrm{CM}$ and HM was determined in this work. The mice in these groups exhibited different allergic symptoms. The mice in the NC group elicited no immune response (score $0=12$ mice). However, the mice in the PC group showed severe allergic reactions; one mouse even died of shock (score $0=0$ mice; score $1=1$ mouse; score 2 or $3=4$ mice; score $4=2$ mice; score $5=1$ mouse). However, the mice in the AT (score $0=2$ mice; score $1=6$ mice; score $2=2$ mice; score $3=1$ mouse; score $4=1$ mouse; score $5=0$ mice), PT (score $0=1$ mouse; score $1=5$ mice; score $2=2$ mice; score $3=3$ mice; score $4=1$ mouse; score $5=0$ mice), and FT groups (score $0=1$ mouse; score $1=6$ mice; score 2 or $3=2$ mice; score $4=1$ mouse; score $5=0$ mice) showed mild allergic symptoms compared with the PC group. Figure 3 shows the changes of body weight from the beginning $(0 \mathrm{~d})$ to the end $(28 \mathrm{~d})$ of this experiment. The weight of all the groups differed significantly. The mice in the NC group weighed the most, and the mice in the PC group weighed the least. However, the mice in the AT, PT, and FT groups presented mild weight loss compared with the PC group.

\section{Cutaneous Test}

As shown in Figure 4, no blue color was observed in the NC group, which showed a negative skin test. Nota- bly, dark blue color was observed in the forefeet of mice in the PC group; anaphylactic mice had remarkably increased vascular permeability, with marked Evan's blue extravasation visible on the forefoot, correlating with clinical symptoms and body weight. By contrast, light blue color was observed in the mice of the AT, $\mathrm{PT}$, and FT groups, which was similar to the mice in the NC group.

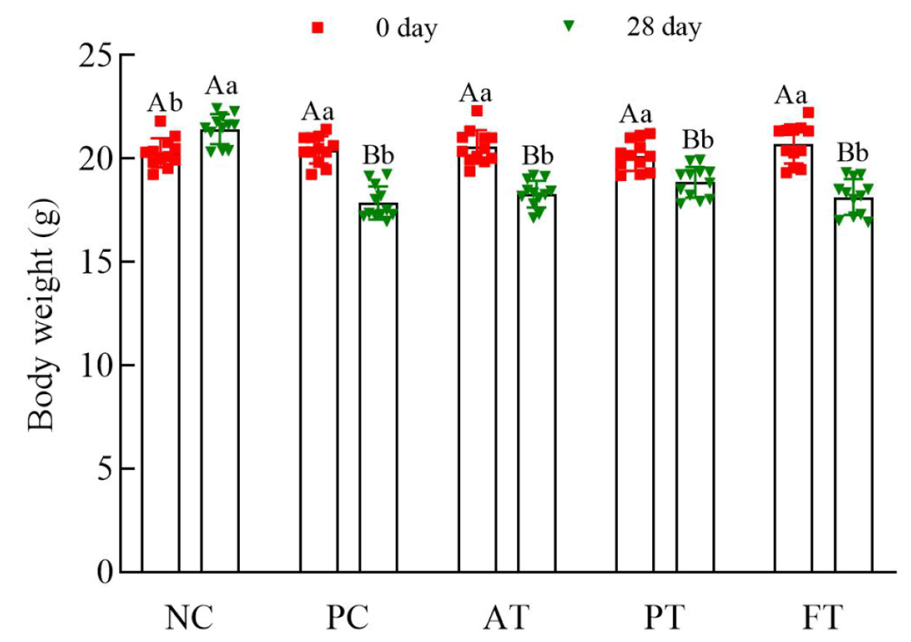

Figure 3. Body weights of studied mice before mice were euthanized by dislocation. $\mathrm{NC}=$ negative control group, $\mathrm{PC}=$ positive control group, $\mathrm{AT}=$ Alcalase-treated cow milk, $\mathrm{PT}=$ Protamex-treated cow milk, FT $=$ Flavourzyme-treated cow milk. All enzymes were purchased from Novozymes. Different letters indicate significant differences $(P<0.05)$ : different uppercase letters indicate differences between groups; different lowercase letters indicate differences within groups. Error bars represent SD. 


\section{Histopathological Analysis of Lungs, Jejunums, and Spleens}

As shown in Figure 5, obvious changes of the lungs, jejunum, and spleen in the PC group were detected. Lungs of the PC group showed hyperplasia of the bronchial lining epithelium, severe hyperemia, thickening of alveolar septa, as well as severe damage to the tissue structure (Figure 5A). Jejunums of the PC group suggested that the mucosal lining was destroyed, with a large number of inflammatory cells infiltrated, villi swelling, and irregularity (Figure 5B). In addition, the spleens of the PC group demonstrated lymphoid hyperplasia, and the lymph nodes were severely damaged, accompanied by a small number of infiltrated inflammatory cells, and the white and red pulp boundaries were not clear (Figure 5C). However, the histopathological changes in the AT, PT, and FT groups were not obvious, compared with the $\mathrm{PC}$ group.

\section{Assessment of Total Antibody Levels}

The levels of total $\operatorname{IgG}_{1}$ and $\operatorname{IgG}_{2 \mathrm{a}}$ were evaluated in this study (Figure 6A, B). In the PC group, the total $\mathrm{IgG}_{1}$ levels significantly increased compared with the AT, PT, and FT groups (all $P<0.05$ ). Interestingly, the total $\mathrm{IgG}_{2 \mathrm{a}}$ levels significantly decreased in the PC group but significantly increased in the AT, PT, and FT groups (all $P<0.05$ ).

\section{Assessment of $C D 4^{+} T$ and $C D 8^{+} T$ Cells}

To characterize $\mathrm{T}$ cells in the spleens of the mice, the numbers of $\mathrm{CD} 4^{+} \mathrm{T}$ and $\mathrm{CD} 8^{+} \mathrm{T}$ cells $\left(\mathrm{CD} 3^{+} \mathrm{CD} 4^{+}\right.$ and $\mathrm{CD} 3^{+} \mathrm{CD} 8^{+}$) were measured through flow cytometry. Figure 7 shows that the number of $\mathrm{CD} 4^{+} \mathrm{T}$ cells was significantly reduced in the PC group (NC vs. PC group: $23.57 \%$ vs. $14.15 \% ; P<0.05$ ). Notably, the numbers of $\mathrm{CD}^{+} \mathrm{T}$ cells in the AT, PT, FT groups significantly increased compared with the PC group (all
$P<0.05)$. In addition, the numbers of $\mathrm{CD}^{+} \mathrm{T}$ cells followed a pattern that contrasted with the changes in $\mathrm{CD}^{+} \mathrm{T}$ cells, with the numbers of $\mathrm{CD}^{+} \mathrm{T}$ cells significantly decreasing in those groups (AT, PT, and FT groups: $P<0.05$, compared with the PC group). In addition, analysis of $\mathrm{CD} 4^{+} / \mathrm{CD} 8^{+} \mathrm{T}$ cells suggested significant differences among the groups (all $P<0.05$ ). In addition, compared with the NC group, a significant decrease occurred in the $\mathrm{PC}$ group, but the ratio of $\mathrm{CD}^{+} / \mathrm{CD}^{+} \mathrm{T}$ cell gradually increased in the AT, PT, and FT groups.

\section{Proportion of B Cells}

To quantify the $\mathrm{B}$ cells in the spleens of the mice, the numbers of B cells (B220 $0^{+}$cells) among mouse splenocytes were measured in this study (Figure 8). The numbers of $\mathrm{B} 220^{+}$cells were highest in the PC group $(44.99 \%)$ and lowest in the NC group (31.28\%), with significant difference between them $(P<0.05)$. Specifically, the numbers of $\mathrm{B} 220^{+}$cells gradually decreased in the AT, PT, and FT groups, compared with the PC group (all $P<0.05$ )

\section{DISCUSSION}

Enzymatic hydrolysis is a common and effective processing technology for reducing the immunoreactivity of CM. At present, many infant formulas that contain enzymatically hydrolyzed proteins have been widely used to feed infants and children with allergy or food intolerance (Osborn and Sinn, 2006). In this work, the effects of enzymatic hydrolysis on allergenicity of CM were systematically studied. Our findings showed that the immunoreactivity of $\mathrm{CM}$ was reduced, especially for $\mathrm{E} / \mathrm{S} 6,000 \mathrm{U} / \mathrm{g}$, for which the reduction in immunoreactivity was significantly different from other E/S. However, when papain reached $6,000 \mathrm{U} / \mathrm{g}$, the immunoreactivity significantly increased. Thus, we speculate that this might be related to the types, specificity
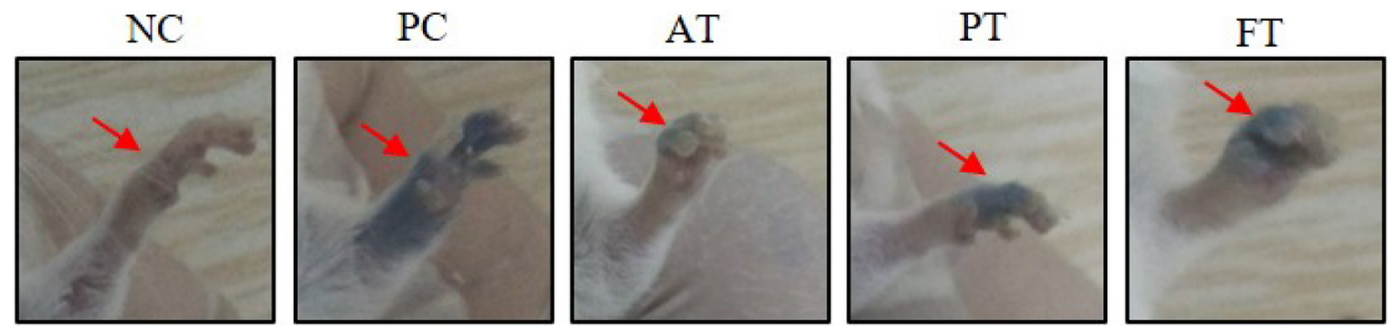

Figure 4. Cutaneous tests of the mice. $\mathrm{NC}=$ negative control group, $\mathrm{PC}=$ positive control group, AT $=$ Alcalase-treated cow milk, $\mathrm{PT}=$ Protamex-treated cow milk, FT = Flavourzyme-treated cow milk. All enzymes were purchased from Novozymes. No color represents vascular permeability unchanged; light blue color represents vascular permeability decreased; and dark blue color represents vascular permeability increased. 
(A)

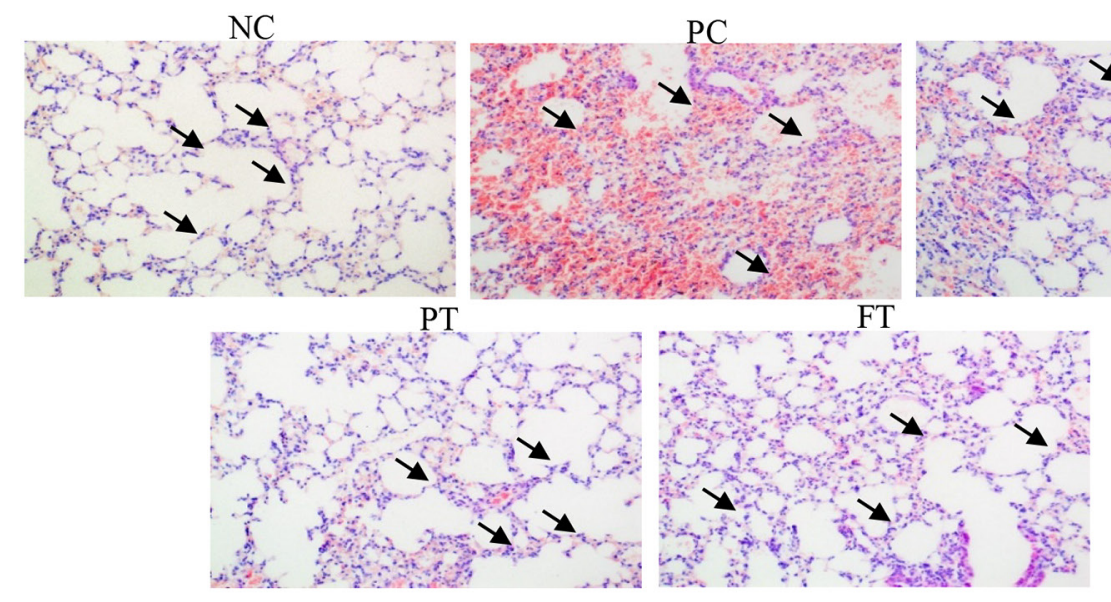

(B)
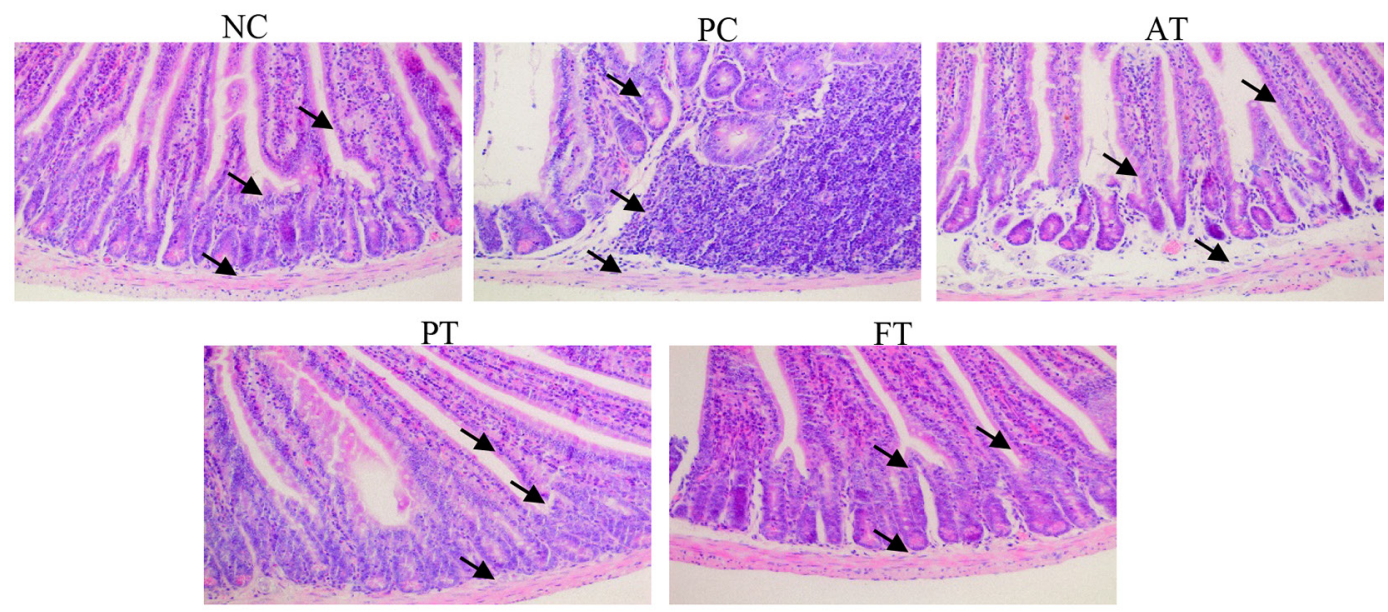

(C)
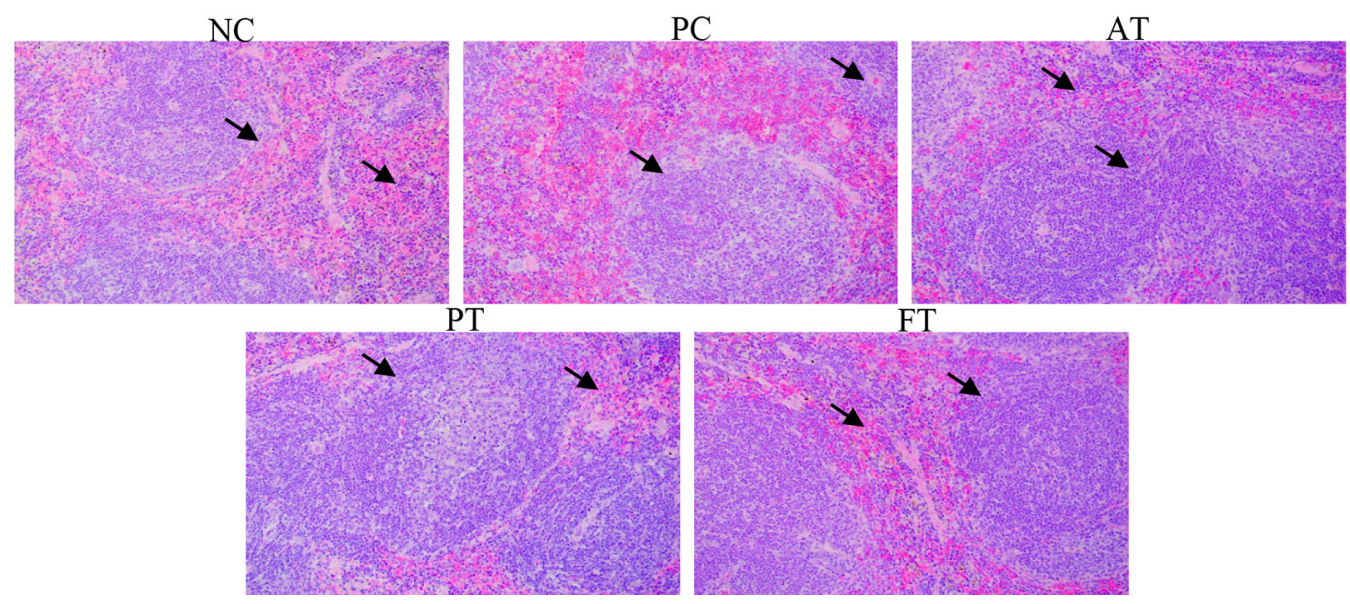

Figure 5. Histopathological analysis of lung (A, arrows point at alveolar septa), jejunum (B, arrows point at villi or inflammatory cells), and spleen from tested mice $(\mathrm{C}$, arrows point at cell aggregation). $\mathrm{NC}=$ negative control group, $\mathrm{PC}=$ positive control group, $\mathrm{AT}=\mathrm{Alcalase-treated}$ cow milk, PT = Protamex-treated cow milk, FT = Flavourzyme-treated cow milk. All enzymes were purchased from Novozymes. 
of the enzyme, and enzymatic hydrolysis conditions. Similarly, Cheison et al. (2007) also proved that the degree of hydrolysis of CM proteins is influenced by the enzymatic hydrolysis conditions, specificity, and types of enzymes. Shi and colleagues detected the IgE binding capacity of $\mathrm{CN}$ and whey protein in Lactobacillus casei-ferment treated $\mathrm{CM}$, and found a reduction from $15 \%$ to $90 \%$ compared with CM (Shi et al., 2014). In addition, Quintieri et al. (2017) demonstrated that noticeable residual $\beta$-LG content was found in the papainhydrolyzed whey protein concentrate sample.

Enzymatic hydrolysis can disrupt conformational or linear epitopes, alter the structure of allergens thereby interfering with the degree of binding of antigens and antibodies, decrease IgE binding capacity, and prevent
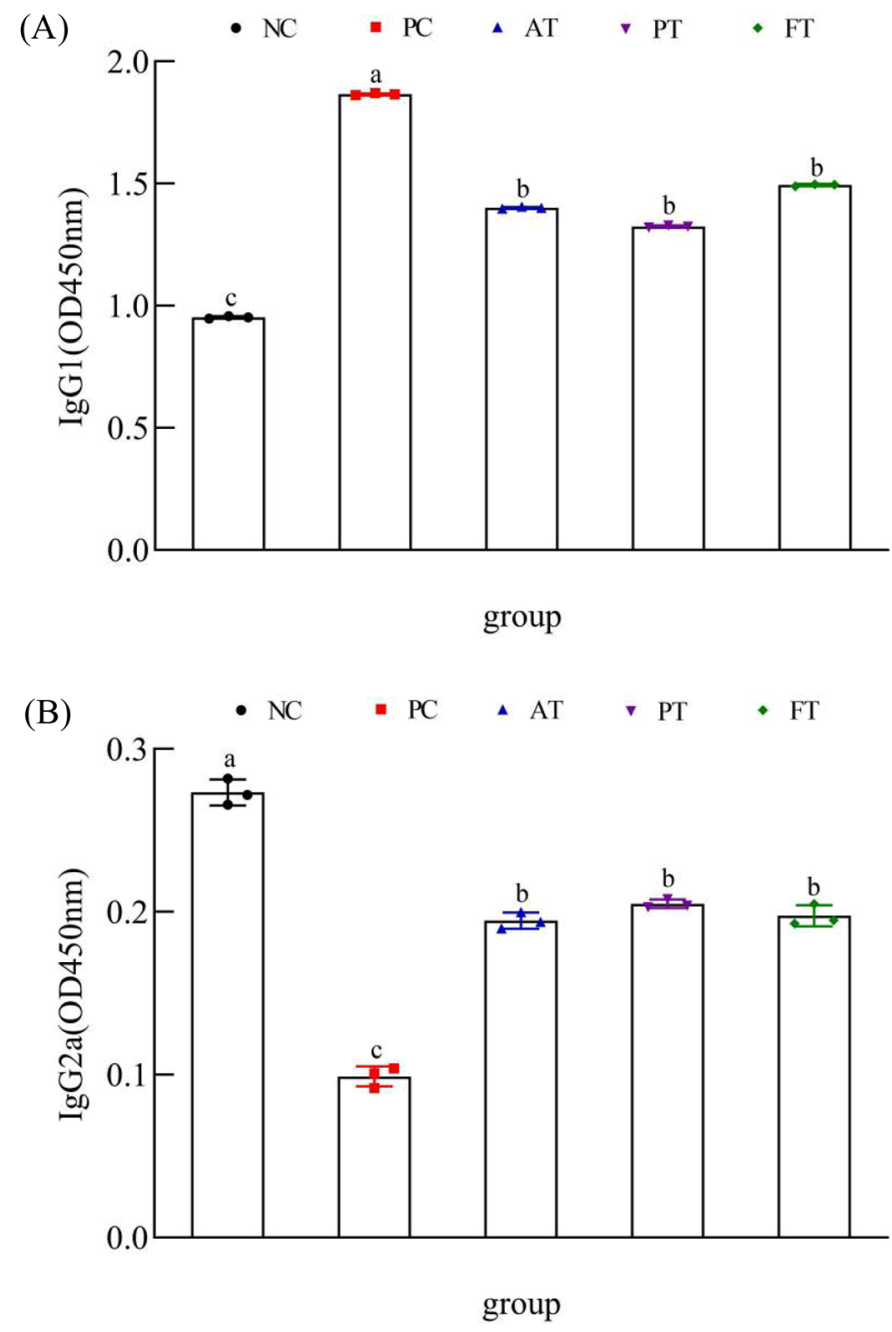

Figure 6. Total $\mathrm{IgG}_{1}$ and $\operatorname{IgG}_{2 \mathrm{a}}$ levels. $\mathrm{NC}=$ negative control group, $\mathrm{PC}=$ positive control group, $\mathrm{AT}=$ Alcalase-treated cow milk, $\mathrm{PT}=$ Protamex-treated cow milk, FT $=$ Flavourzyme-treated cow milk. All enzymes were purchased from Novozymes. Different letters indicate significant differences $(P<0.05)$. OD450nm $=$ optical density at $450 \mathrm{~nm}$. The error bars represent SD.
IgE-mediated allergic reactions (Yang et al., 2020). Some studies have showed that alterations of amino acids in $\beta$-LG might damage certain epitopes, leading to loss of IgE binding capacity (Karisola, 2002). In this study, this phenomenon was confirmed by western blotting. Our findings demonstrated that the IgE binding capacity of $\alpha$-LA decreased in HM, and the IgE binding of CM obtained with Alcalase was weaker than that of Protamex and Flavourzyme, indicating that $\alpha$-LA might be less resistant to Alcalase hydrolysis. Similarly, other studies demonstrated that Ara h 3 is sensitive to Alcalase hydrolysis and exhibits weak $\operatorname{IgE}$ binding capacity (Yu and Mikiashvili, 2020). Yu et al. (2019) suggested that Alcalase was more effective in reducing the immunoreactivity of $\mathrm{CM}$ proteins than other enzymes, as it significantly lowered the $\operatorname{IgE}$ and $\operatorname{IgG}$ binding capacities of whey protein.

Animal models are an important biological tool to assess the allergenicity of foods or proteins. Some studies have shown that BALB/c mice orally challenged with food allergens exhibit clinical allergic symptoms, such as nose and mouth scratching, reduced activity, shivering, diarrhea, and decreased body weight (Verma et al., 2012). In this work, the clinical signs, changes in body weight, and cutaneous test were observed, to evaluate the allergic reactions of the mice. The findings indicated that the mice in the PC group showed anaphylactic reactions from mild to lethal, whereas the AT, PT, and FT groups exhibited minor anaphylactic symptoms. In addition, weight losses in the AT, PT, and FT groups were not noticeably different from the PC group. These results indicate that HM could reduce allergic reactions in mice. Bai et al. (2020) monitored changes in BW of BALB/c mice before oral sensitization and challenge, and found that the weights of the soybean group was higher than that of experimental groups. Moreover, Meng et al. (2016) also observed the anaphylactic symptoms of BALB/c mice administered with $\alpha-\mathrm{LA}$ and irradiated $\alpha-\mathrm{LA}$, which suggested that the mice administered with $\alpha$-LA developed anaphylactic reactions, whereas the mice challenged with irradiated $\alpha$-LA showed no anaphylactic reactions.

Food allergy not only causes various clinical symptoms but also severely engenders the histopathological changes in multiple organs, such as the intestine, lung, spleen, and ear (Chen et al., 2017). Thus, the effects of enzymatic hydrolysis on the histopathological changes in organs of the mice also were observed. In this study, the structure of the lungs, jejunum, and spleen in the PC group were damaged, whereas the inflammation in the AT-, PT-, and FT-group mice was relieved significantly. The structure of the jejunum and intestinal villi may be destroyed following inflammation, which may lead to the disappearance of intestinal villi (Noti 
(A)
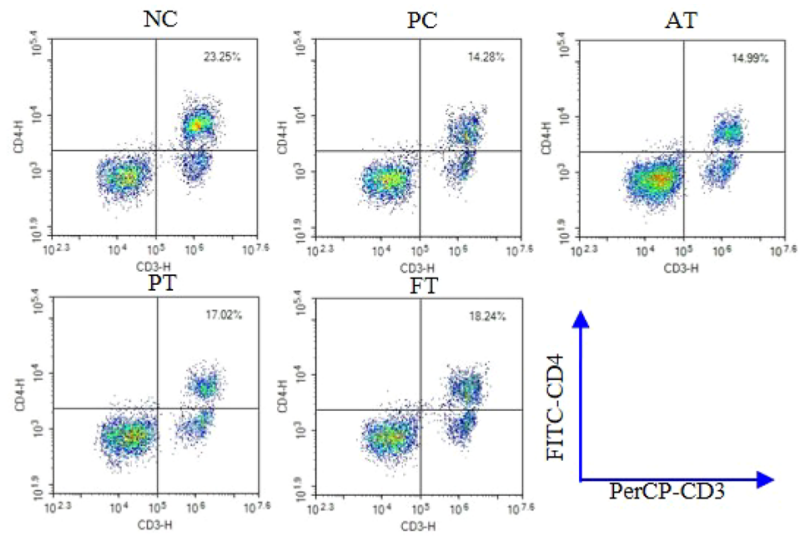

- $\mathrm{NC}$

- PC
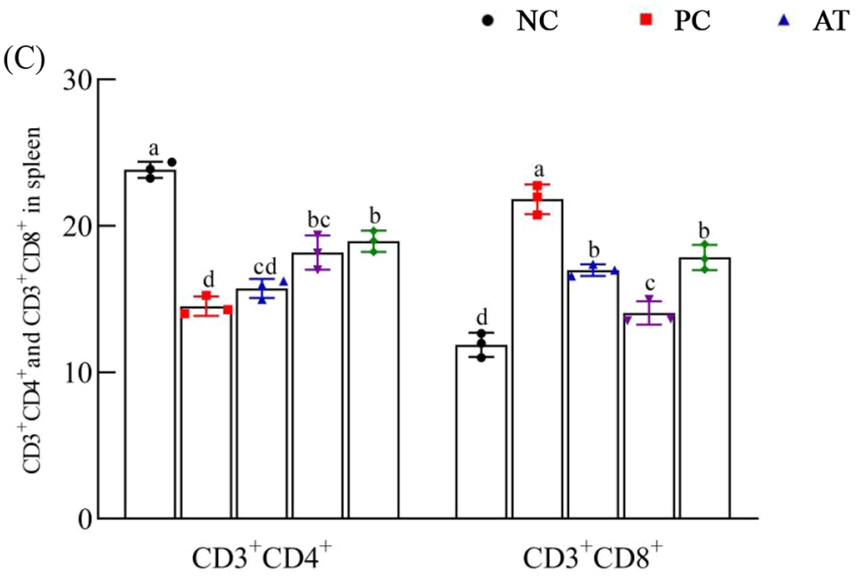

(B)
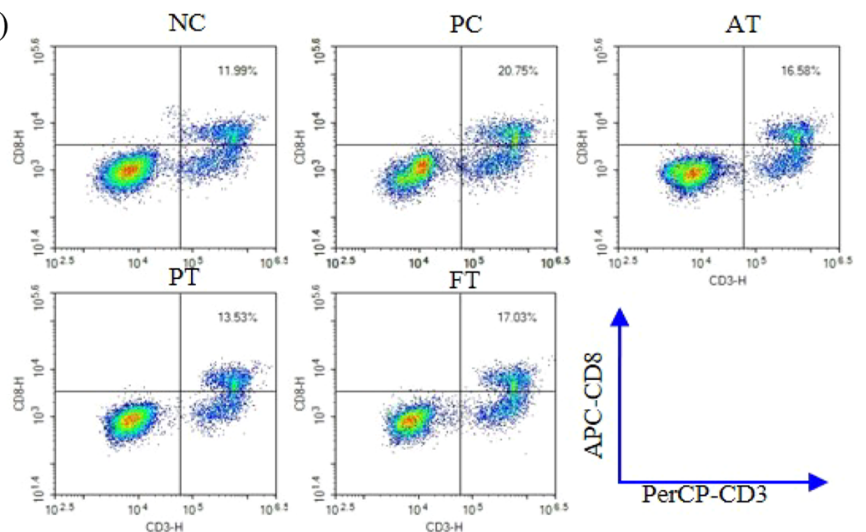

Figure 7. Differentiation balance of $\mathrm{CD} 3^{+} \mathrm{CD} 4^{+}$and $\mathrm{CD} 3^{+} \mathrm{CD} 8^{+}$in spleen cells of the studied mice. (A) Expression of $\mathrm{CD} 3^{+} \mathrm{CD} 4^{+}$. $(\mathrm{B})$ Expression of $\mathrm{CD}^{+} \mathrm{CD}^{+}$. (C) Percentage of $\mathrm{CD} 3^{+} \mathrm{CD} 4^{+}$and $\mathrm{CD} 3^{+} \mathrm{CD} 8^{+}$expression. (D) $\mathrm{CD} 4^{+} / \mathrm{CD} 8^{+}$ratios. $\mathrm{NC}=$ negative control group, $\mathrm{PC}$ $=$ positive control group, AT $=$ Alcalase-treated cow milk, $\mathrm{PT}=$ Protamex-treated cow milk, FT = Flavourzyme-treated cow milk. All enzymes were purchased from Novozymes. Different letters indicate significant differences $(P<0.05)$. Error bars represent SD. FITC $=$ fluorescein isothiocyanate; $\mathrm{APC}=$ allophycocyanin; $\mathrm{PERCP}=$ peridinin chlorophyll protein complex.

et al., 2014). Similarly, Kumar et al. (2018) demonstrated that the lungs and intestine of mice treated with Buchanania lanzan protein suggested infiltration of inflammatory cells, blocking the airway and causing asthma.

Previous findings have suggested that the immunomodulation of hydrolysates might be an underlying mechanism, resulting in the hypoallergenic properties of hydrolyzed whey proteins (Gill et al., 2000). Lee et al. (2013) demonstrated that $\operatorname{IgE}, \operatorname{IgG}_{1}$, and $\operatorname{IgG}_{2 \mathrm{a}}$ are the most critical molecules in allergic responses. Thus, we evaluated total $\operatorname{IgG}_{1}$ and $\operatorname{IgG}_{2 \mathrm{a}}$ levels. These findings showed that total $\mathrm{IgG}_{1}$ levels significantly increased in the $\mathrm{PC}$ group, and the $\operatorname{IgG}_{2 \mathrm{a}}$ levels showed an opposite phenomenon. Some studies have reported that the egg protein ovalbumin induced increase in $\mathrm{IgE}$ and reduction in $\mathrm{IgG}_{2 \mathrm{a}}$, compared with heated ovalbumin (Golias et al., 2012). Similarly, Kiewiet et al. (2017) also found that significant increases of $\operatorname{IgE}$ and $\mathrm{IgG}_{1}$ levels were determined in partially hydrolyzed whey proteins, which is in agreement with our results.

$\mathrm{T}$ lymphocytes are distributed in the immune organs and tissues of the body; $\mathrm{CD} 4^{+} \mathrm{T}$ and $\mathrm{CD} 8^{+} \mathrm{T}$ cells are important subgroups of $\mathrm{T}$ lymphocytes, as they perform vital immune functions. Th cells called CD4 ${ }^{+}$ T cells have the function of assisting humoral immunity and cellular immunity (Miyoshi et al., 2020), and cytotoxic $\mathrm{T}$ cells $(\mathrm{Tc})$ cells called $\mathrm{CD} 8^{+} \mathrm{T}$ cells have the ability to kill target cells and regulate the IgE response (Weigmann et al., 2006). In the healthy body, the ratio of $\mathrm{CD} 4^{+} \mathrm{T}$ to $\mathrm{CD} 8^{+} \mathrm{T}$ cells is maintained at a stable level, but once the body's immune system is damaged, this balance is disrupted. In our study, HM significantly increased the numbers of $\mathrm{CD} 4^{+} \mathrm{T}$ cells but reduced the numbers of $\mathrm{CD}^{+} \mathrm{T}$ cells, mitigated $\mathrm{CD} 4^{+} \mathrm{T} /$ $\mathrm{CD}^{+} \mathrm{T}$ cell imbalance, and relieved allergic reactions 
in the mice. Studies have showed some changes of $\mathrm{T}$ cell subsets in infants and children with CMA, with an obviously lower percentage of $\mathrm{CD} 4^{+} \mathrm{T}$ cells compared with the control group (Bobrus-Chociej et al., 2018). Trigo et al. (2009) suggested that the levels of IgG, $\mathrm{CD} 4^{+} \mathrm{T}$, and $\mathrm{CD} 8^{+} \mathrm{T}$ cells in BALB/c mice infected by Streptococcus agalactiae were significantly decreased.

When B lymphocyte cells are stimulated by foreign antigens, they can differentiate and proliferate into plasma cells, which synthesize antibodies and exert humoral immunity (Jelinek, 2000). Previous studies have shown that Th cells of the spleen play an important role in activating and class-switching of B lymphocyte cells, which have a great influence on food allergy (Coffman et al., 1988). Thus, this study also explored whether HM affected the number of B lymphocyte cells in the mice. Our results suggested that, compared with the $\mathrm{NC}$ group, the numbers of $\mathrm{B} 220^{+}$cells increased in the
PC group, but the AT, PT, and FT groups showed decreasing trends. These results indicate that HM can inhibit the expression levels of B lymphocyte cells in humoral immunity, thereby affecting the secretion of specific antibodies and reducing the immune response in the sensitization and excitation phases.

In conclusion, enzymatic hydrolysis with Alcalase, Protamex, and Flavourzyme has the potential to reduce the immunoreactivity of $\mathrm{CM}$ in vitro. Moreover, in vivo results also indicated that $\mathrm{HM}$ attenuated anaphylactic symptoms, suppressed levels of $\operatorname{IgG}_{1}$, and relieved allergic inflammation in mice. Furthermore, $\mathrm{HM}$ mitigated the $\mathrm{CD} 4^{+} \mathrm{T} / \mathrm{CD} 8^{+} \mathrm{T}$ cell imbalance and inhibited the expression levels of B lymphocyte cells. Thus, enzymatic hydrolysis treatment with Alcalase, Protamex, and Flavourzyme could effectively reduce the sensitization of CM. Our results could lay a foundation for milk production companies in the development
(A)
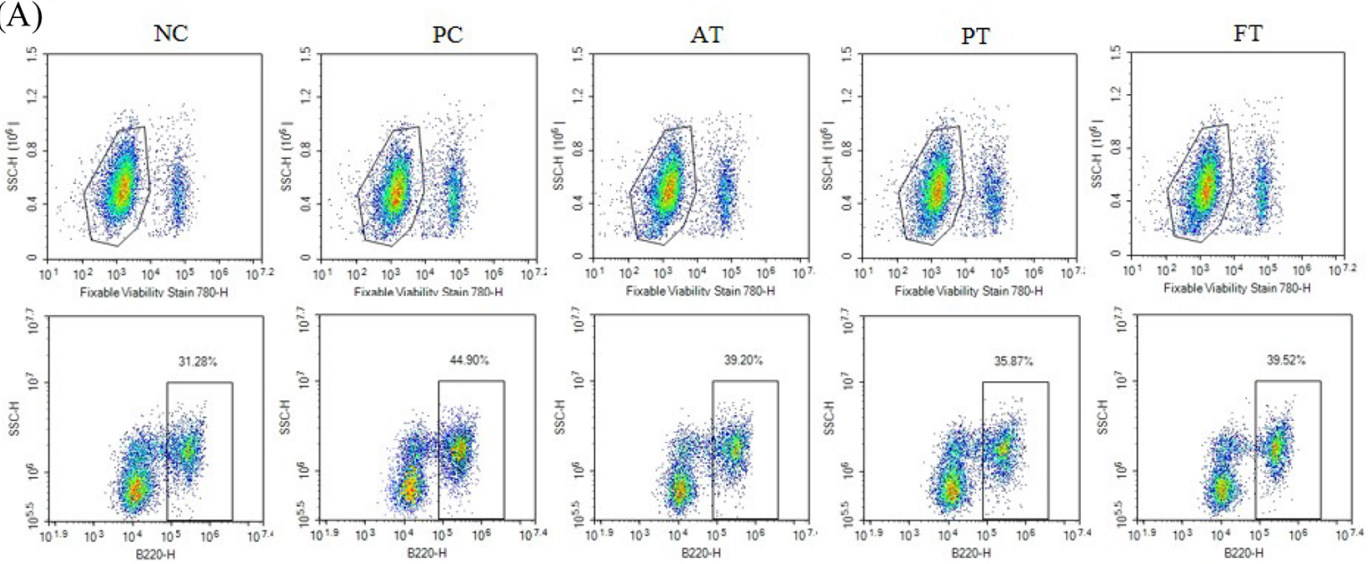

(B)

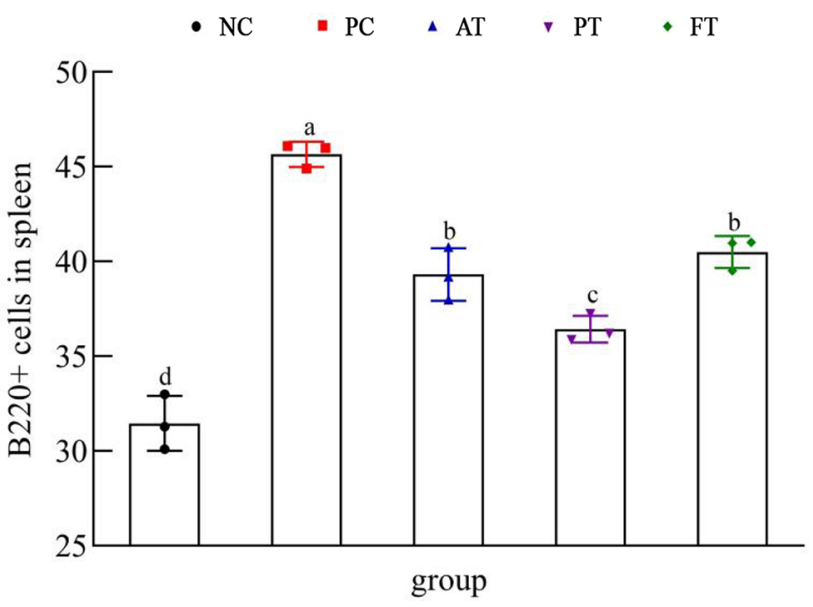

Figure 8. Identification of B220 cells in spleens of studied mice. (A) Expression of B220 ${ }^{+}$cells in the mice. (B) Percentages of B220 ${ }^{+}$cell populations. $\mathrm{NC}=$ negative control group, $\mathrm{PC}=$ positive control group, $\mathrm{AT}=$ Alcalase-treated cow milk, $\mathrm{PT}=\mathrm{Protamex}$-treated cow milk, FT $=$ Flavourzyme-treated cow milk. All enzymes were purchased from Novozymes. Different letters indicate significant differences $(P<0.05)$. Error bars represent SD. 
of high-quality hypoallergenic CM products. However, enzymatic hydrolysis of $\mathrm{CM}$ resulted in some small peptides with a certain extent of allergenicity. Thus, these peptides need to be identified and inactivated in further research. In addition, the effects of enzymatic hydrolysis on sensory properties, nutritional qualities, and storage stability of CM, as well as the cost of enzymatic hydrolysis treatment and consumer affordability of allergen-reduced CM, also need to be comprehensively evaluated in the future.

\section{ACKNOWLEDGMENTS}

This work was supported by the by National Key $\mathrm{R}$ \& D Program of China (Beijing; grant number 2018YFC1604302-03). The authors have not stated any conflicts of interest.

\section{REFERENCES}

Bai, J., J. Hui, Q. Lu, A. Yang, J. Yuan, J. Gao, Z. Wu, X. Li, P. Tong, and H. Chen. 2020. Effect of transglutaminase cross-linking on the allergenicity of tofu based on a BALB/c mouse model. Food Funct. 11:404-413. https://doi.org/10.1039/C9FO02376C.

Ballmer-Weber, B. K., and M. Fernández-Rivas. 2008. Food allergy: A clinician's criteria for including sera in a serum bank. Food Chem. Toxicol. 46(Suppl. 10):S2-S5.

Bobrus-Chociej, A., U. Daniluk, M. Alifier, A. Stasiak-Barmuta, and M. G. Kaczmarski. 2018. Alterations of lymphocyte subpopulations and TGF- $\beta$ in children with transient or persistent cow's milk allergy. Food Agric. Immunol. 29:400-411. https://doi.org/10 $.1080 / 09540105.2017 .1387234$.

Burney, P., C. Summers, S. Chinn, R. Hooper, R. van Ree, and J. Lidholm. 2010. Prevalence and distribution of sensitization to foods in the European Community Respiratory Health Survey: A EuroPrevall analysis. Allergy 65:1182-1188. https://doi.org/10.1111/j $.1398-9995.2010 .02346 . x$.

Calvo, M. M., and R. Gómez. 2002. Peptidic profile, molecular mass distribution and immunological properties of commercial hypoallergenic infant formulas. Milchwissenschaft 57:187-190.

Candreva, A. M., P. L. Smaldini, R. Curciarello, C. A. Fossati, G. H. Docena, and S. Petruccelli. 2016. The major soybean allergen Gly $\mathrm{m} \mathrm{Bd} 28 \mathrm{~K}$ induces hypersensitivity reactions in mice sensitized to cow's milk proteins. J. Agric. Food Chem. 64:1590-1599. https:// doi.org/10.1021/acs.jafc.5b05623.

Cheison, S. C., Z. Wang, and S. Y. Xu. 2007. Use of macroporous adsorption resin for simultaneous desalting and debittering of whey protein hydrolysates. Int. J. Food Sci. Technol. 42:1228-1239. https://doi.org/10.1111/j.1365-2621.2006.01461.x.

Chen, C., L. Lu, N. Sun, Y. Li, and X. Jia. 2017. Development of a BALB/c mouse model for food allergy: Comparison of allergyrelated responses to peanut agglutinin, $\beta$-lactoglobulin and potato acid phosphatase. Toxicol. Res. (Camb.) 6:251-261. https://doi .org/10.1039/C6TX00371K.

Coffman, R. L., B. W. P. Seymour, D. A. Lebman, D. D. Hiraki, J. A. Christiansen, B. Shrader, H. M. Cherwinski, H. F. J. Savelkoul, F. D. Finkelman, M. W. Bond, and T. R. Mosmann. 1988. The role of helper $\mathrm{T}$ cell products in mouse $\mathrm{B}$ cell differentiation and isotype regulation. Immunol. Rev. 102:5-28. https://doi.org/10.1111/ j.1600-065X.1988.tb00739.x.

El-Hatmi, H., Z. Jrad, I. Salhi, A. Aguibi, A. Nadri, and T. Khorchani. 2015. Comparison of composition and whey protein fractions of human, camel, donkey, goat and cow milk. Mljekarstvo 65:159167. https://doi.org/10.15567/mljekarstvo.2015.0302.
Elagamy, E. I. 2000. Effect of heat treatment on camel milk proteins with respect to antimicrobial factors: A comparison with cows' and buffalo milk proteins. Food Chem. 68:227-232. https://doi.org/10 .1016/S0308-8146(99)00199-5.

Gill, H. S., F. Doull, K. J. Rutherfurd, and M. L. Cross. 2000. Immunoregulatory peptides in bovine milk. Br. J. Nutr. 84(Suppl. 1):S111-S117. https://doi.org/10.1017/S0007114500002336.

Golias, J., M. Schwarzer, M. Wallner, M. Kverka, H. Kozakova, D. Srutkova, K. Klimesova, P. Sotkovsky, L. Palova-Jelinkova, F. Ferreira, and L. Tuckova. 2012. Heat-induced structural changes affect OVA-antigen processing and reduce allergic response in mouse model of food allergy. PLoS One 7:e37156. https://doi.org/10 .1371/journal.pone.0037156.

Hsieh, K. Y., C. I. Hsu, J. Y. Lin, C. C. Tsai, and R. H. Lin. 2003. Oral administration of an edible-mushroom-derived protein inhibits the development of food-allergic reactions in mice. Clin. Exp. Allergy 33:1595-1602. https://doi.org/10.1046/j.1365-2222.2003.01790.x.

Jelinek, D. F. 2000. Regulation of B lymphocyte differentiation. Ann. Allergy Asthma Immunol. 84:375-386.

Karisola, P. 2002. The major conformational IgE-binding epitopes of Hevein (Hev b6.02) are identified by a novel chimera-based allergen epitope mapping strategy. J. Biol. Chem. 277:22656-22661.

Kiewiet, M. B. G., B. C. A. M. van Esch, J. Garssen, M. M. Faas, and P. de Vos. 2017. Partially hydrolyzed whey proteins prevent clinical symptoms in a cow's milk allergy mouse model and enhance regulatory $\mathrm{T}$ and $\mathrm{B}$ cell frequencies. Mol. Nutr. Food Res. 61:1700340. https://doi.org/10.1002/mnfr.201700340.

Kumar, S., A. Sharma, R. K. Gupta, A. K. Verma, and P. D. Dwivedi. 2018. Allergenicity assessment of Buchanania lanzan protein extract in Balb/c mice. Int. Immunopharmacol. 63:170-182. https:/ /doi.org/10.1016/j.intimp.2018.07.039.

Lee, J., J. Bang, and H.-J. Woo. 2013. Effect of orally administered Lactobacillus brevis HY7401 in a food allergy mouse model. J. Microbiol. Biotechnol. 23:1636-1640.

Lee, J.-W., J.-H. Kim, H.-S. Yook, K.-O. Kang, S.-Y. Lee, H.-J. Hwang, and M.-W. Byun. 2001. Effects of gamma radiation on the allergenic and antigenic properties of milk proteins. J. Food Prot. 64:272-276. https://doi.org/10.4315/0362-028X-64.2.272.

Liang, X., H. Yang, J. Sun, J. Cheng, X. Luo, Z. Wang, M. Yang, D. Bing Tao, X. Yue, and Y. Zheng. 2021. Effects of enzymatic treatments on the hydrolysis and antigenicity reduction of natural cow milk. Food Sci. Nutr. 9:985-993. https://doi.org/10.1002/fsn3 2066 .

Meng, X., X. Li, J. Gao, and H. Chen. 2016. Characterization of the potential allergenicity of irradiated bovine $\alpha$-lactalbumin in a BALB/c mouse model. Food Chem. Toxicol. 97:402-410. https:// doi.org/10.1016/j.fct.2016.10.010.

Miyoshi, T., K. Itani, M. Kobayashi, and S. Imashuku. 2020. CD4/ CD8+ adult T-cell leukemia/lymphoma with unusual morphology presenting as ascites and pleural effusion. Int. J. Lab. Hematol. 42:e105-e106.

National Research Council (US), Institute for Laboratory Animal Research. 1996. Guide for the Care and Use of Laboratory Animals. National Academies Press. Accessed Apr. 7, 2021. https://www .ncbi.nlm.nih.gov/books/NBK232589/.

Noti, M., B. S. Kim, M. C. Siracusa, G. D. Rak, M. Kubo, A. E. Moghaddam, Q. A. Sattentau, M. R. Comeau, J. M. Spergel, and D. Artis. 2014. Exposure to food allergens through inflamed skin promotes intestinal food allergy through the thymic stromal lymphopoietin-basophil axis. J. Allergy Clin. Immunol. 133:13901399. https://doi.org/10.1016/j.jaci.2014.01.021.

Oliveira, J. P. B., A. M. Candreva, G. Rizzo, M. V. Ramos, J. S. Oliveira, H. D. Oliveira, M. B. Ary, G. Docena, and C. D. T. Freitas. 2019. Allergenicity reduction of cow's milk proteins using latex peptidases. Food Chem. 284:245-253.

Osborn, D. A., and J. Sinn. 2006. Formulas Containing Hydrolysed Protein for Prevention of Allergy and Food Intolerance in Infants. John Wiley \& Sons.

Petruláková, M., and U. Valík. 2015. Food allergy and intolerance. Acta Chim. Slov. 8. 
Quintieri, L., L. Monaci, F. Baruzzi, M. G. Giuffrida, S. de Candia, and L. Caputo. 2017. Reduction of whey protein concentrate antigenicity by using a combined enzymatic digestion and ultrafiltration approach. J. Food Sci. Technol. 54:1910-1916. https://doi .org/10.1007/s13197-017-2625-5.

Schouten, B., B. C. A. M. Van Esch, G. A. Hofman, S. A. C. M. Van Doorn, J. Knol, A. J. Nauta, J. Garssen, L. E. M. Willemsen, and L. M. J. Knippels. 2009. Cow milk allergy symptoms are reduced in mice fed dietary synbiotics during oral sensitization with whey. J. Nutr. 139:1398-1403. https://doi.org/10.3945/jn.109.108514.

Shi, J., Y. Luo, Y. Xiao, Z. Li, Q. Xu, and M. Yao. 2014. Effects of fermentation by Lactobacillus casei on the antigenicity and allergenicity of four bovine milk proteins. Int. Dairy J. 35:75-80.

Stojadinovic, M., P. Raymond, S. Joost, and V. T. Cirkovic. 2014. Cross-linking of $\beta$-lactoglobulin enhances allergic sensitization through changes in cellular uptake and processing. Toxicol. Sci. 140:224-235.

Toheder, R., T. Vasiljevic, and L. Ramchandran. 2016. Effect of processing on conformational changes of food proteins related to allergenicity. Trends Food Sci. Technol. 49:24-34. https://doi.org/ 10.1016/j.tifs.2016.01.001

Trigo, G., M. Dinis, Â. França, E. Bonifácio Andrade, R. M. Gil da Costa, P. Ferreira, and D. Tavares. 2009. Leukocyte populations and cytokine expression in the mammary gland in a mouse model of Streptococcus agalactiae mastitis. J. Med. Microbiol. 58:951958. https://doi.org/10.1099/jmm.0.007385-0

Verma, A. K., S. Kumar, A. Tripathi, B. P. Chaudhari, M. Das, and P. D. Dwivedi. 2012. Chickpea (Cicer arietinum) proteins induce allergic responses in nasobronchial allergic patients and BALB/c mice. Toxicol. Lett. 210:24-33. https://doi.org/10.1016/j.toxlet 2012.01.011.

Weigmann, B., E. R. Jarman, S. Sudowe, M. Bros, J. Knop, and A. B. Reske-Kunz. 2006. Induction of regulatory T cells by leflunomide in a murine model of contact allergen sensitivity. J. Invest. Dermatol. 126:1524-1533. https://doi.org/10.1038/sj.jid.5700228.

Wróblewska, B., and A. Troszyñska. 2005. Enzymatic hydrolysis of cows whey milk proteins in the aspect of their utilization for the production of hypoallergenic formulas. Pol. J. Food Nutr. Sci. 14.
Wu, Z., J. Lian, Y. Han, N. Zhou, X. Li, A. Yang, P. Tong, and H. Chen. 2016. Crosslinking of peanut allergen Ara h 2 by polyphenol oxidase: Digestibility and potential allergenicity assessment. J. Sci. Food Agric. 96:3567-3574.

Yadav, A., A. Kumar, A. Tripathi, and M. Das. 2013. Sunset yellow FCF, a permitted food dye, alters functional responses of splenocytes at non-cytotoxic dose. Toxicol. Lett. 217:197-204. https:// doi.org/10.1016/j.toxlet.2012.12.016.

Yang, A., L. L. Zuo, Y. Cheng, Z. Wu, X. Li, P. Tong, and H. Chen. 2018. Degradation of major allergens and allergenicity reduction of soybean meal through solid-state fermentation with microorganisms. Food Funct. 9:1899-1909. https://doi.org/10.1039/ C7FO01824J.

Yang, H., Y. Qu, J. Li, X. Liu, J. Wu, and J. Wu. 2020. Improvement of the protein quality and degradation of allergens in soybean meal by combination fermentation and enzymatic hydrolysis. Lebensm. Wiss. Technol. 128:109442. https://doi.org/10.1016/j.lwt.2020 109442 .

Yang, X., J. Sun, J. Tao, Y. Ma, J. Wei, and F. Long. 2017. The allergenic potential of walnuts treated with high pressure and heat in a mouse model of allergy. Innov. Food Sci. Emerg. Technol. 39:165-170.

Yu, J., and N. Mikiashvili. 2020. Effectiveness of different proteases in reducing allergen content and IgE-binding of raw peanuts. Food Chem. 307:125565. https://doi.org/10.1016/j.foodchem.2019 .125565 .

Yu, X., C. Liu, M. Lu, Y. Liu, J. Yin, and Y. Zhang. 2019. Impact of enzymatic hydrolysis followed by transglutaminase-induced crosslinking on decreasing antigenicity and reserving partial interfacial properties of whey protein isolate. Food Funct. 10:1653-1660.

\section{ORCIDS}

Xiaona Liang (1) https://orcid.org/0000-0001-8678-4747

Xiqing Yue $\odot$ https://orcid.org/0000-0001-5558-1461 